\title{
EFFECT OF WELDING ON MICROSTRUCTURE AND CORROSION PROPERTIES OF SAF 2507 SUPER-DUPLEX STAINLESS-STEEL JOINTS
}

\author{
VPLIV POGOJEV VARJENJA NA MIKROSTRUKTURO IN \\ KOROZIJSKE LASTNOSTI ZVAROV IZ SAF 2507 SUPER \\ DUPLEKS NERJAVNEGA JEKLA
}

\author{
Kai Qi', Mingfang Wu' ${ }^{1}$, Jiayang Gu${ }^{2}$, Yanxin Qiao', Ruifeng $\mathbf{L i}^{1}$ \\ 1Jiangsu University of Science and Technology, School of Materials Science and Engineering, 2 Mengxi Road, Zhenjiang 212003, China \\ 2Jiangsu University of Science and Technology, Marine Equipment and Technology Institute, 2 Mengxi Road, Zhenjiang 212003, China
}

Prejem rokopisa - received: 2019-11-11; sprejem za objavo - accepted for publication: 2020-08-05

doi:10.17222/mit.2019.275

In this paper, SAF 2507 super-duplex stainless steel (SDSS) was welded using laser-beam welding (LBW), laser gas-metal hybrid arc welding (LGH) and gas-tungsten arc welding (GTAW). Heat-input calculation results showed that LBW had the lowest heat input, while GTAW had the highest heat input. The correlation of the heat input during the welding with the microstructure, nanoindentation properties and corrosion behaviors of the three types of welded joints of SAF 2507 SDSS was studied. The hardness of the welded joints decreased as the heat input increased. Microstructural analyses showed that these welded joints were composed of the ferrite phase and austenite phase, and that the fraction of the austenite phase increased with the heat input. Electrochemical studies indicated that the heat input had a minor influence on the corrosion behavior of these joints. A slight increase in the passive-current density and acceptor/donor density in the passive film suggested that the heat input slightly increased the corrosion susceptibility by changing the structure and property of the passive film formed on the surface of the welded joints.

Keywords: super-duplex stainless steel, welding, elastic property, corrosion, electrochemical

V članku avtorji opisujejo raziskavo vplivov načinov varjenja na SAF 2507 super dupleks (austenitno/feritno) nerjavno jeklo (SDSS). Izbrali so naslednje postopke izdelave varjenih jeklenih spojev: varjenje z laserskim snopom (LBW), obločno hibridno varjenje kovine s plinskim laserjem (LGH) in plinsko obločno varjenje z volframovo elektrodo (GTAW). Izračuni so pokazali, da so dosegli najmanjši vnos toplote pri varjenju z LBW-postopkom in največjega pri GTAW-postopku. Avtorji so študirali povezavo med vnosom toplote, vnešene $\mathrm{v}$ material med varjenjem ter mikrostrukturo zvarov, lastnostmi povezanimi $z$ merjenjem nanotrdote in korozijske lastnosti izdelanih SAF 2507 SDSS-zvarov, glede na vse tri izbrane postopke varjenja. Ugotovili so, da se z naraščajočim vnosom energije (toplote) varjenja zmanjšuje trdota zvarnih spojev. Mikrostrukturne analize so pokazale, da je mikrostruktura vseh zvarnih spojev sestavljena iz feritne in austenitne faze in, da delež austenitne faze narašča z naraščajočim vnosom toplote. Elektrokemijske študije so pokazale, da ima vnos toplote zanemarljiv vpliv na korozijske lastnosti zvarov. Rahlo povečanje pasivne tokovne gostote in gostote toka akceptor/donor (sprejemnik/darovalec) v pasivnem filmu nakazujeta, da povečanje vnosa toplote rahlo poveča korozijsko občutljivost zaradi spremembe mikrostrukture zvarov in lastnosti pasivnega filma, nastalega med izdelavo zvarnih spojev.

Ključne besede: super dupleks nerjavno jeklo, varjenje, elastične lastnosti, korozija, elektrokemija

\section{INTRODUCTION}

Super-duplex stainless steel (SDSS) is an important engineering material that has been widely used in a variety of industries and environments owing to its good mechanical properties and high corrosion resistance. The excellent corrosion resistance of SDSS is mainly due to the increase in the $\mathrm{Cr}, \mathrm{Mo}$ and $\mathrm{N}$ alloying contents, which promote the formation of a compact and chemically stable oxide film. ${ }^{1-4}$ Welding is an important fabrication technique for SDSS. ${ }^{5}$ However, the rapid heating and cooling rates of a welding process have a great influence on the microstructure of a welded joint. ${ }^{6-9}$ The discontinuous distribution of alloying elements and various precipitated particles may have a negative effect on the

*Corresponding author's e-mail: qikai@just.edu.cn (Kai Qi) corrosion resistance of welded joints. ${ }^{10}$ It is reported that laser-beam welding (LBW), ${ }^{5}$ laser gas-metal hybrid arc welding (LGH) and gas-tungsten arc welding (GTAW) ${ }^{11}$ have been successfully applied for joining SDSSs. However, the heat input during a welding process alters the initial ratio of the ferrite phase to austenite phase, ${ }^{12}$ thus changing the mechanical properties and corrosion properties of welded joints. ${ }^{3,13-15}$ These findings ${ }^{3,13-15}$ show that the heat input has a significant influence on the impact toughness of welded joints. A low heat input leads to a higher ferrite content and higher chromium nitride precipitation, while a high heat input and/or a long exposure between $1200{ }^{\circ} \mathrm{C}$ and $400{ }^{\circ} \mathrm{C}$ promote the precipitation of brittle phases like $\sigma$ and $\chi$. However, the influence of the heat input on the nanoindentation response and corrosion behaviors of SDSS is still poorly understood. 
K. QI et al.: EFFECT OF WELDING ON MICROSTRUCTURE AND CORROSION PROPERTIES ...

Table 1: Chemical compositions (w/\%) of SAF 2507 and SAF 2594

\begin{tabular}{|l|c|c|c|c|c|c|c|c|c|c|c|}
\hline & $\mathrm{C}$ & $\mathrm{Si}$ & $\mathrm{Mn}$ & $\mathrm{P}$ & $\mathrm{S}$ & $\mathrm{Ni}$ & $\mathrm{Cr}$ & $\mathrm{Mo}$ & $\mathrm{Cu}$ & $\mathrm{N}$ & $\mathrm{Fe}$ \\
\hline SAF 2507 & 0.019 & 0.18 & 0.76 & 0.026 & 0.005 & 6.4 & 25.7 & 3.3 & 0.14 & 0.66 & Bal. \\
\hline SAF 2594 & 0.011 & 0.43 & 0.41 & 0.017 & 0.004 & 9.34 & 25.19 & 3.92 & 0.093 & 0.23 & Bal. \\
\hline
\end{tabular}

In the present work, microstructural modifications of a SAF 2507 SDSS sheet were studied using LBW, LGH and GTAW. In addition, the corrosion and passivation performance of these welded joints in a $3.5-\% \mathrm{NaCl}$ solution were determined.

\section{EXPERIMENTAL DETAILS}

The material used in the present study was a SAF 2507 (UNS S32750) SDSS sheet with a thickness of $5 \mathrm{~mm}$. The welding wire used was SAF 2594. Their chemical compositions $(w / \%)$ are listed in Table 1. The mechanical and preparation methods used to achieve the welding parameters were described in detail elsewhere. ${ }^{5}$ The heat input is a combined effect of the welding power and the scanning speed, and the heat-input values for LBW, LGH and GTAW were $108.24 \mathrm{~J} / \mathrm{m}, 255.04 \mathrm{~J} / \mathrm{m}$ and $280.31 \mathrm{~J} / \mathrm{m}$, respectively. ${ }^{16}$ The microstructure of these welded joints was observed using a scanning election microscope (SEM, JSM-6460). The micro-hardness measurements of individual phases were performed at a fixed interval using an MH-5 tester with a load of $100 \mathrm{~g}$ and a loading time of $15 \mathrm{~s}$. The average value of five measurements was used to represent the hardness of a specimen.

To characterize the effect of a welding processes on the micromechanical properties of the ferrite $(\delta)$ and austenite phase $(\gamma)$, nanoindentation curves were acquired using a CSM NHT2 nanoindenter (Anton Paar) at a maximum load of $20 \mathrm{mN}$, with a loading/unloading rate of $40 \mathrm{mN} \cdot \mathrm{min}^{-1}$. In the nanoindentation tests, the micromechanical behavior of the ferrite phase and austenite phase was analyzed using the depth-recovery ratio $\left(\eta_{\mathrm{h}}\right)$ obtained from the load-displacement curves. ${ }^{17}$ The samples were studied using D8 X-ray diffraction with a $\mathrm{Cu}$ $\mathrm{K}_{\mathrm{a}}$ radiation, generated at $40 \mathrm{kV}$ and $35 \mathrm{~mA}$.

All the electrochemical measurements were performed within a standard three-electrode system in a 1.5 L electrochemical cell using a model Corrtest CS350 potentiostat/galvanostat, and the method was already described in the literature. ${ }^{18,19}$ The test solution was $3.5 w / \% \mathrm{NaCl}$ solution prepared with analytical-grade $\mathrm{NaCl}$ and deionized water. Experiments were carried out at $25 \pm 1{ }^{\circ} \mathrm{C}$ in a naturally aerated solution without stirring. Potentiodynamic polarization was measured after CE was performed for $15 \mathrm{~min}$, with a scanning rate of $0.333 \mathrm{mV} / \mathrm{s}$ from $-300 \mathrm{mV}$ below the open-circuit potential (OCP) and terminated when a current value of $20 \mathrm{~mA} / \mathrm{cm}^{2}$ was reached. Mott-Schottky (M-S) measurements were started at $-1000 \mathrm{mV}_{\mathrm{SCE}}$ and scanned up to $200 \mathrm{mV}_{\mathrm{SCE}}$ at a sweep rate of $10 \mathrm{mV}$. All the electro- chemical tests were repeated at least three times to ensure the reproducibility. Prior to the M-S measurement, the working electrodes were initially polarized at $-1200 \mathrm{~V}_{\mathrm{SCE}}$ for $120 \mathrm{~s}$ to reduce air-formed oxides and then passivated at $400 \mathrm{mV}_{\mathrm{SCE}}$ for $30 \mathrm{~min}$.

\section{RESULTS AND DISCUSSION}

\subsection{Microstructural characterization}

The microstructure of SAF2507 after different welding processes is shown in Figure 1. The morphology of
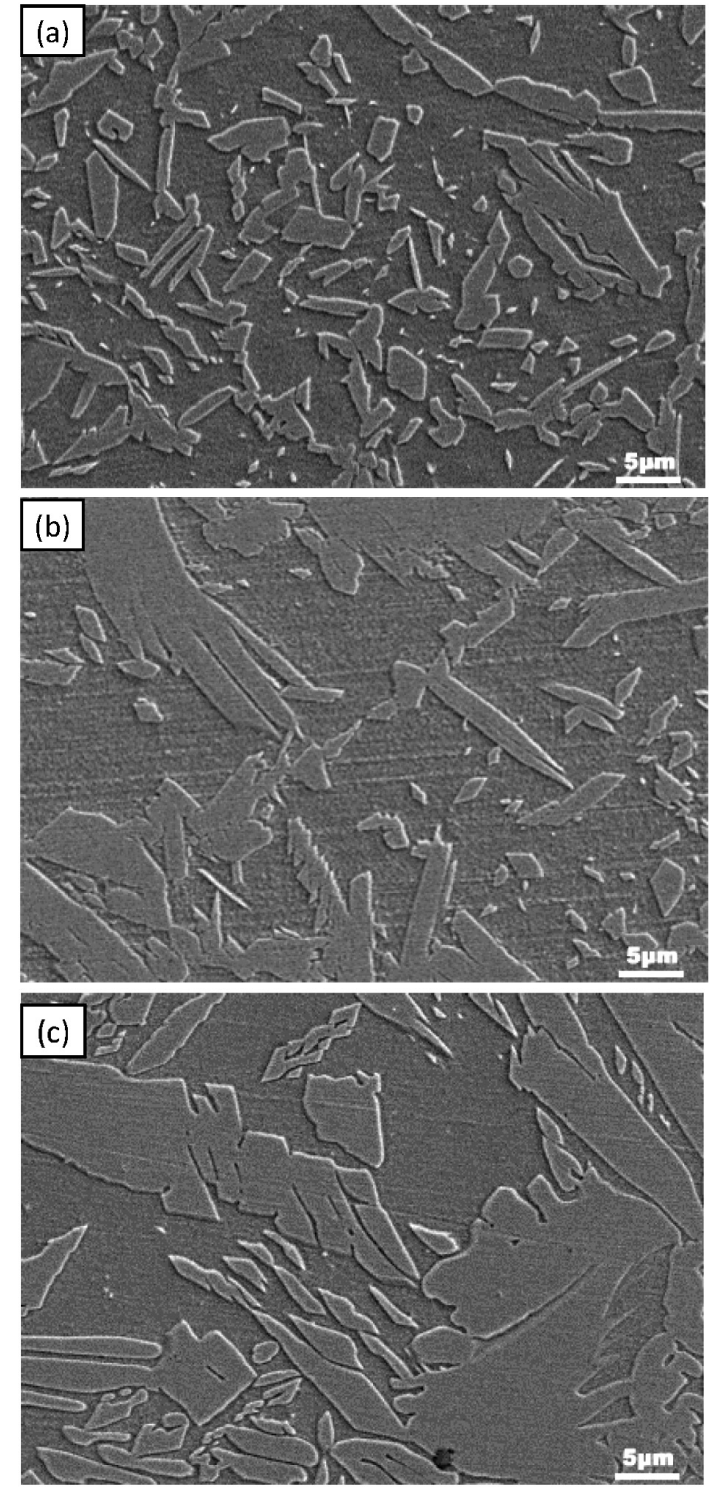

Figure 1: SEM observations of: a) LBW, b) LGH and GTAW welded joints 


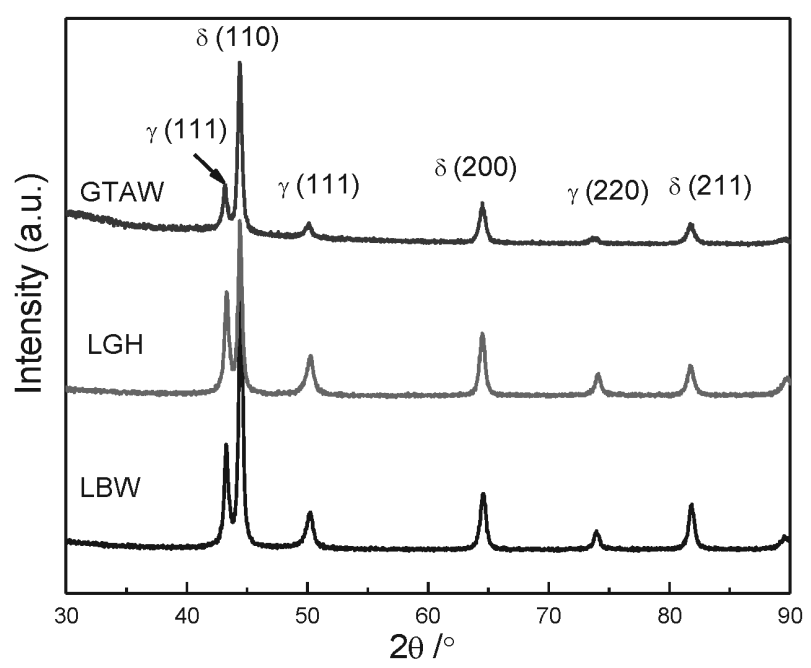

Figure 2: XRD patterns of the SAF 2507 welded joints

the $\gamma$ phase of the LBW welded joint was irregular, being allotriomorphic at the prior $\delta$-grain boundaries as Widmanstätten side-plates in the grains from the allotriomorphs and as intergranular precipitates, ${ }^{5,20}$ as shown in Figure 1a. The microstructure of the LGH welded joint shown in Figure 1b was somewhat similar to the LBW welded joint, except that the grain size and proportion of the $\gamma$ phase were slightly larger. The grain size and proportion of the $\gamma$ phase further increased in the GTAW welded joint as shown in Figure 1c. It is clear that no secondary phase precipitated either in the grains or at the grain boundaries.

The presence of different phases within the SAF 2507 welded joints was identified using XRD, as shown in Figure 2. It can be seen that the predominant diffractions came from the $\gamma$ and $\delta$ phases, which is consistent with the results of the microstructure observation. As illustrated in Figure 1, a gradual increase in the $\delta$-phase volume fraction was observed with the increase in the heat input. The image analysis using Image-Pro Plus (IPP) revealed that the $\gamma$ volume fraction was $46 \%, 53 \%$ and $72 \%$ for the LBW, LGH and GTAW welded joint, respectively. During welding, the weld metal solidified as the $\delta$ phase, which was further partially transformed into the $\gamma$ phase during the cooling stage, and the rate of the $\delta$ to $\gamma$ transformation was dependent on the material composition and cooling rate. ${ }^{20}$

\subsection{Nanoindentation test}

Figure 3 shows the load-displacement curves (P-h) of the $\gamma$ phase and $\delta$ phase in the SAF 2507 welded joints. It can be seen that the hardness of the $\gamma$ phase is slightly higher than that of the $\delta$ phase in these three welded joints, as suggested by the lower penetration depth in the $\gamma$ phase. Datta ${ }^{21}$ reported that the ferritic phase has higher elastic-modulus and hardness values than the austenitic phase, which is expected since the $\gamma$ phase is softer. However, this result is consistent with the results of Garcia-Junceda, ${ }^{22}$ who investigated the elastic modulus and nano-hardness of the $\gamma$ phase and $\alpha$ phase of sintered SDSSs. The higher elastic modulus and hardness of the $\gamma$ phases can be attributed to three factors: the high local misorientation values generated at the $\gamma / \alpha$ interface or a higher deformation resistance; 22 the smaller grain size of the interfacial constituents compared to the $\alpha$ and $\gamma$ phases, which enhance the mechanical properties of the steel due to the Hall-Petch relationship; ${ }^{11,23,24}$ the presence of the $\sigma$ phase (the strongest and hardest constituent in SDSSs). ${ }^{22}$

The maximum indentation depth $\left(h_{\max }\right)$, the residual depth after unloading $\left(h_{\mathrm{r}}\right)$ and the hardness of the stainless steel $\left(H_{\mathrm{d}}\right)$ are given in Table 2 . The elastic properties $\left(\eta_{\mathrm{h}}\right)$ of both the $\gamma$ phase and $\delta$ phase did not change with the welding process. It is seen in Table 2 that the $H_{\mathrm{d}}$ for both the $\gamma$ and $\delta$ phases decreased with the heat input during the welding process. These results are consistent with the results from $\mathrm{Li}^{8}$ about the hardness distributions of the welded joint of $\mathrm{Cr} 18 \mathrm{Mn} 18 \mathrm{~N}$ with different heat inputs, finding that the hardness of the joints decreased as the heat input increased.
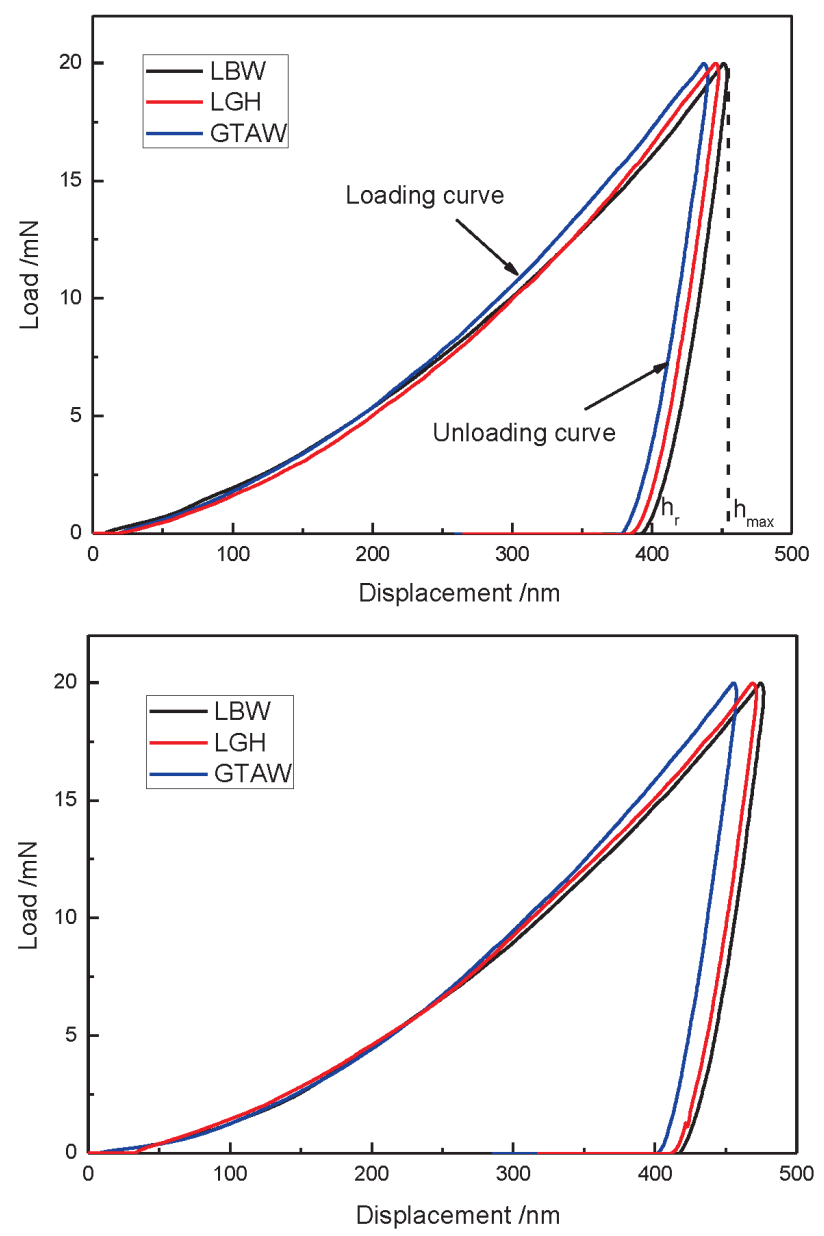

Figure 3: a) Load-penetration depth curves of the $\gamma$ phase and b) $\delta$ phase for SAF 2507 welded joints 
Table 2: Indentation parameters derived from the load-displacement curves in Figure 3

\begin{tabular}{|c|c|c|c|c|c|c|}
\hline Phase & $\begin{array}{c}\text { Welding } \\
\text { process }\end{array}$ & $\begin{array}{c}h_{\max } \\
(\mathrm{nm})\end{array}$ & $h_{\mathrm{r}}(\mathrm{nm})$ & $\eta_{\mathrm{h}}$ & $\begin{array}{c}H_{\mathrm{d}} \\
(\mathrm{GPa})\end{array}$ & HV100 \\
\hline \multirow{3}{*}{$\gamma$} & LBW & 453.4 & 392.8 & 0.134 & $442 \pm 5$ & $280 \pm 5$ \\
\cline { 2 - 7 } & LGH & 447.5 & 385.9 & 0.138 & $435 \pm 7$ & $283 \pm 9$ \\
\cline { 2 - 7 } & GTAW & 439.9 & 379.2 & 0.138 & $412 \pm 6$ & $277 \pm 6$ \\
\hline \multirow{3}{*}{$\delta$} & LBW & 476.7 & 417.8 & 0.124 & $433 \pm 8$ & $293 \pm 8$ \\
\cline { 2 - 7 } & LGH & 471.3 & 413.4 & 0.123 & $413 \pm 11$ & $290 \pm 7$ \\
\cline { 2 - 7 } & GTAW & 457.5 & 402.4 & 0.120 & $394 \pm 9$ & $291 \pm 11$ \\
\hline
\end{tabular}

\subsection{Electrochemical behavior}

Figure 4 shows the open-circuit-potential (OCP) results for the SAF 2507 welded joint after different welding processes in the $3.5 \% \mathrm{NaCl}$ solution. After having been exposed to air, the surfaces of the welded joints were covered with a layer of oxide film. ${ }^{25}$ To minimize the influence of air-formed oxides on the corrosion behavior of the welded joints, the welded specimens were potentiostatically held at $-1.2 \mathrm{~V}_{\mathrm{SCE}}$ for $120 \mathrm{~s}$ to reduce the air-formed oxides, followed by the measurement of the OCP. ${ }^{18}$ The spontaneous OCP after the immersion indicated the growth of the corrosion products on the joint surface in the $3.5 \% \mathrm{NaCl}$ solution with the increased immersion time. The available literature suggests that the passive film composed of $\mathrm{Fe}$ and $\mathrm{Cr}$ oxides formed on the surface of the SAF2507 welded joint when exposed to a $3.5 \% \mathrm{NaCl}$ solution. ${ }^{18,26-29}$ It can be seen that the OCPs were around $-0.2 \mathrm{~V}_{\mathrm{SCE}}$ after the immersion in the solution; they gradually shifted to the positive direction and finally reached steady-state potentials. The steadystate potentials for the LBW, LGH and GTAW welded joints were $-58 \mathrm{mV}_{\mathrm{SCE}},-41 \mathrm{mV}_{\mathrm{SCE}}$ and $-67 \mathrm{mV}_{\mathrm{SCE}}$, respectively. The time to reach the steady-state potential for the LBW welded joint was the shortest while that for the GTAW welded joint was the longest. This is consistent with the change in the heat input during the welding process.

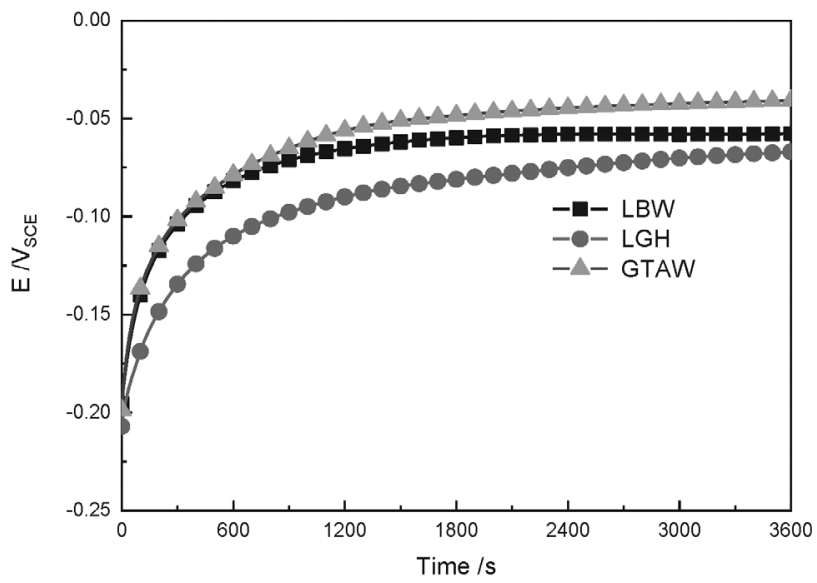

Figure 4: Evolution of the open-circuit potential of the SAF 2507 welded joints in the $3.5 \% \mathrm{NaCl}$ solution with respect to the immersion time
Electrochemical-impedance-spectroscopy (EIS) measurements were carried out to investigate the stability of the passive films formed on the SAF 2507 welded joints after different welding processes. The Nyquist plots of these welded joints, pre-passivated at an applied potential of $400 \mathrm{mV}_{\mathrm{SCE}}$ for $30 \mathrm{~min}$ in the $3.5 \%$ solution are shown in Figure 5. It is seen that the Nyquist diagrams exhibit an unfinished capacitance arc, similar to the materials with superior corrosion resistance in chloride-containing solutions. ${ }^{30-32}$ This type of EIS spectrum is correlated with the corrosion process of a passive film with a high film resistance and a charge-transfer process occurring at the film/solution interface. ${ }^{33}$ The inserted figure in Figure 5 shows the equivalent circuit, used to fit the EIS spectra. It was necessary to use a constant phase element $(\mathrm{CPE})^{27,30,34-36}$ representing the behavior of the capacitor due to the distribution of the relaxation time resulting from the heterogeneities at the electrode surface. The impedance of the CPE is given as:

$$
Z_{\mathrm{CPE}}=\frac{1}{Q}(j \omega)^{-n}
$$

Therefore, the total impedance is: ${ }^{31}$

$$
Z_{\text {total }}=R_{\text {sol }}+\left(Q(j \omega)^{n}+\frac{1+R_{\mathrm{t}} C j \omega}{R_{1}+R_{\mathrm{t}}+R_{1} R_{\mathrm{t}} C j \omega}\right)^{-1}
$$

where $n$ is the depression angle (in degrees) that evaluates the semicircle deformation, $R_{\text {sol }}$ is the electrolyte resistance, $R_{\mathrm{t}}$ represents the charge-transfer resistance, $R_{1}$ corresponds to the film resistance, $Q$ corresponds to the pseudocapacitance of the double layer, expressed using the CPE, and $C$ is the film capacity. Factor $n$, defined as the CPE power, is an adjustable parameter that is always between 0.5 and 1 . Table 3 shows the electric parameters obtained with the equivalent electric circuit fitted to the EIS data. It is observed that the film resistance $\left(R_{\mathrm{t}}\right)$ of the SAF 2507 welded joints slightly decreased with the increasing heat input, suggesting that

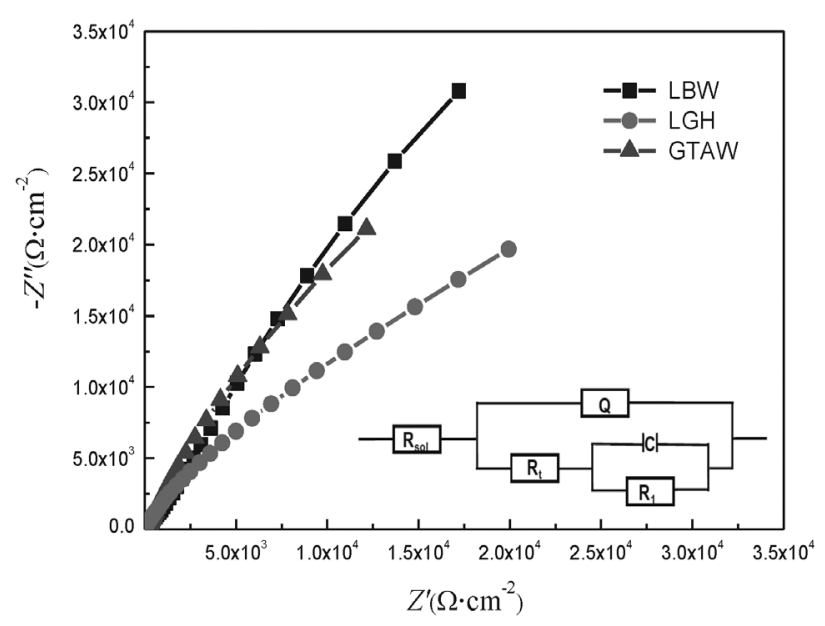

Figure 5: Nyquist plots for the SAF 2507 welded joints in $3.5 \% \mathrm{NaCl}$ solution 
K. QI et al.: EFFECT OF WELDING ON MICROSTRUCTURE AND CORROSION PROPERTIES ...

Table 3: Equivalent circuit parameters of the SAF 2507 welded joints in $3.5 \% \mathrm{NaCl}$ solution

\begin{tabular}{|c|c|c|c|c|c|c|}
\hline & $R_{\text {sol }} / \Omega \cdot \mathrm{cm}^{-2}$ & $Q / \Omega^{-1} \cdot \mathrm{s}^{\mathrm{n}} \mathrm{cm}^{-2}$ & $n$ & $R_{1} / \Omega \cdot \mathrm{cm}^{-2}$ & $C / \mathrm{F} \cdot \mathrm{cm}^{-2}$ & $R_{\mathrm{t}} / \mathrm{k} \Omega \cdot \mathrm{cm}^{-2}$ \\
\hline LBW & 8.65 & $8.32 \times 10^{-5}$ & 0.92 & 27.47 & $2.35 \times 10^{-6}$ & 67.29 \\
\hline LGH & 7.84 & $7.44 \times 10^{-5}$ & 0.92 & 22.45 & $2.25 \times 10^{-6}$ & 58.12 \\
\hline GTAW & 8.33 & $5.75 \times 10^{-5}$ & 0.92 & 20.74 & $1.54 \times 10^{-6}$ & 44.77 \\
\hline
\end{tabular}

the structure and property of the passive film changed with the heat input.

In order to investigate the effects of the welding process on the corrosion behavior of SAF 2507, potentiodynamic-polarization measurements for these welded joints were undertaken in the $3.5 \% \mathrm{NaCl}$ solution. Figure 6 presents the potentiodynamic-polarization curves for the SAF 2507 welded joints in the $3.5 \% \mathrm{NaCl}$ solution. It shows a typical polarization behavior of the passive material, which consisted of oxygen reduction, active dissolution, passivity and a film breakdown. The corrosion potentials $\left(E_{\text {corr }}\right)$ and current densities $\left(i_{\text {corr }}\right)$ obtained in Figure 6 are given in Table 4. It can be seen from Table 4 that there were no significant differences between the corrosion parameters for these three welded joints, suggesting that they had similar electrochemical behaviors. However, the passive-current density was increasing with the increase in the heat input during the welding, which is consistent with the OCP and EIS results.

Table 4: $E_{\text {corr }}$ and $i_{\text {corr }}$ values for the SAF 2507 welded joints in $3.5 \%$ $\mathrm{NaCl}$ solution

\begin{tabular}{|c|c|c|c|}
\hline & LBW & LGH & GTAW \\
\hline$E_{\mathrm{corr}} / \mathrm{mV}_{\mathrm{SCE}}$ & -305 & -333 & -324 \\
\hline$i_{\mathrm{corr}} / \mathrm{A} \cdot \mathrm{cm}^{-2}$ & $4.3 \times 10^{-7}$ & $3.9 \times 10^{-7}$ & $5.8 \times 10^{-7}$ \\
\hline
\end{tabular}

The current-time transients of the SAF2507 welded joints in the $3.5 \% \mathrm{NaCl}$ solution are shown in Figure 7. It was observed that the current density initially decreased rapidly with the time and finally reached a steady-state current density $\left(i_{\mathrm{ss}}\right)$. This is ascribed to the

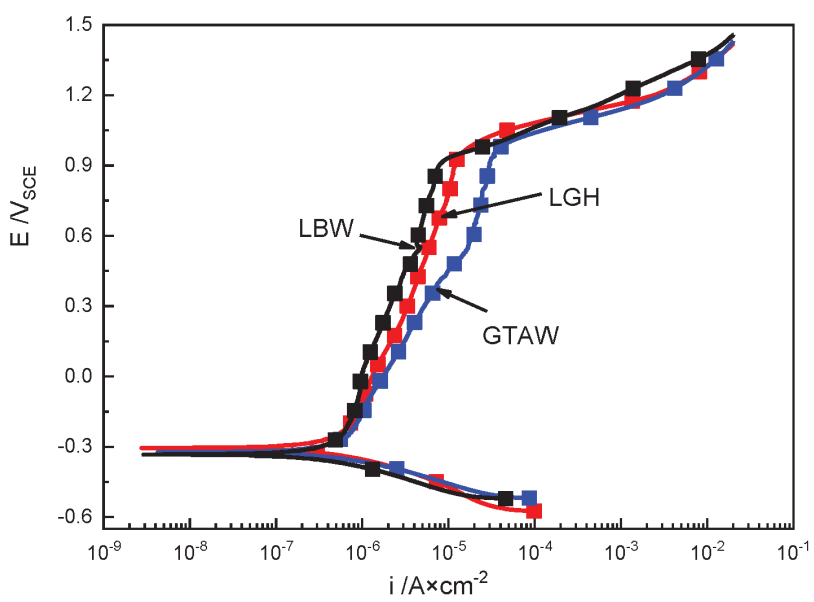

Figure 6: Potentiodynamic-polarization curves for the SAF 2507 welded joints in $3.5 \% \mathrm{NaCl}$ solution nucleation and growth rate of the passive film being faster than the rate of the material dissolution. ${ }^{31}$ The value of the $i_{\mathrm{ss}}$ was observed to be slightly increased with the increasing heat input during the welding process, indicating an inferior protection of the passive film. Generally, the passive films formed on most metals and alloys exhibit a semi-conduction behavior, ${ }^{29,33,37-39}$ and can be determined with the Mott-Schottky (M-S) equation: ${ }^{39}$

$$
\frac{1}{C^{2}}=\frac{1}{C_{\mathrm{H}}^{2}}+\frac{1}{C_{\mathrm{SC}}^{2}}+\frac{2}{\varepsilon \varepsilon_{0} e A N_{\mathrm{q}}}\left(E-E_{\mathrm{fb}}-\frac{k T}{e}\right)
$$

where $C_{\mathrm{H}}$ is the Helmholtz layer capacitance, $C_{\mathrm{SC}}$ is the space-charge capacitance, $N_{\mathrm{q}}$ is the donor/acceptor density in the passive film, $\varepsilon$ is the dielectric constant of the oxide ( 15.6 for the passive film on steel ${ }^{60}$ ), $\varepsilon_{0}$ is the vacuum dielectric constant $\left(8.85 \times 10^{-14} \mathrm{~F} \mathrm{~cm}^{-1}\right), e$ is the electron charge $\left(1.602 \times 10^{-19} \mathrm{C}\right), k$ is the Boltzmann constant $\left(1.38 \times 10^{-23} \mathrm{~J} \mathrm{~K}^{-1}\right), T$ is the absolute temperature, $A$ is the area of sample and $E_{\mathrm{fb}}$ is the flat-band potential.

Figure 8 presents the M-S curves for the passive films formed on the SAF2507 welded joints in the $3.5 \%$ $\mathrm{NaCl}$ solution. In Figure 8, the $\mathrm{M}-\mathrm{S}$ plots show the p-type semiconductive behavior at potentials from -1 to $-0.6 \mathrm{~V}_{\mathrm{SCE}}$, and the n-type semiconductive behavior at potentials from -0.6 to $0 \mathrm{~V}_{\mathrm{SCE}}$. This implies that the passive films formed had at least two layers exhibiting the behavior of a p-n junction. ${ }^{26}$ The donor concentration in the passive film is exhibited by the slope of the linear part in Figure 8. The decrease in the positive slopes of the M-S curves from -0.6 to $0 \mathrm{~V}_{\mathrm{SCE}}$ with the increase in the heat input indicates that the donor concentration in the passive film increased. The donor density $\left(N_{\mathrm{A}}\right)$ obtained in

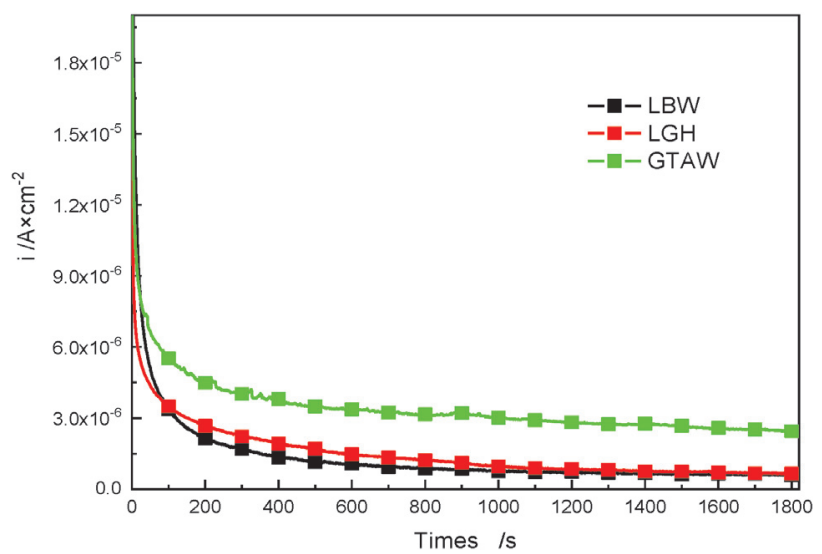

Figure 7: Current-time transients for SAF 2507 welded joints in $3.5 \% \mathrm{NaCl}$ solution 


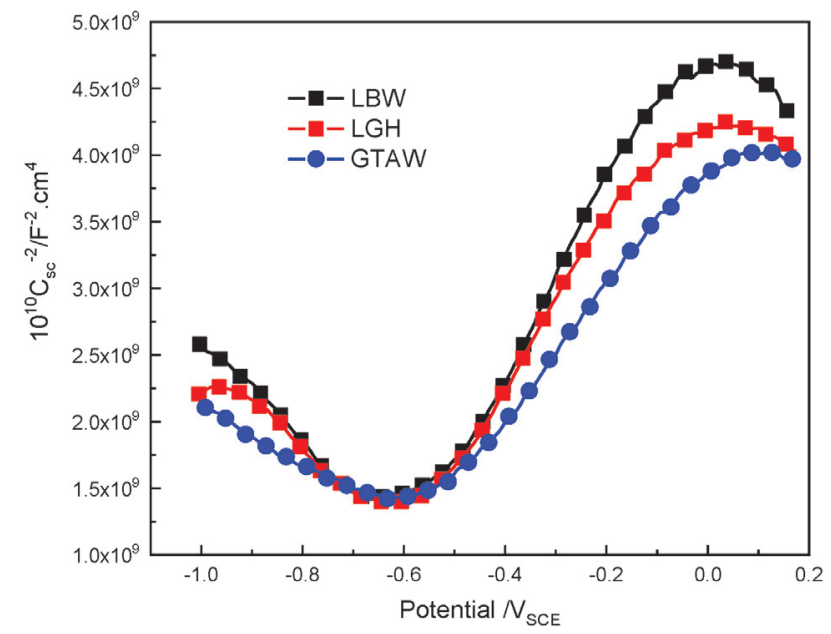

Figure 8: Mott-Schottky plots of the SAF 2507 welded joints in $3.5 \% \mathrm{NaCl}$ solution

Figure 8 is presented in Table 5. It was observed that the donor density increased with the increase in the heat input during the welding process. This observation was consistent with the electrochemical measurements such as the measurements of the OCP, potentiodynamic polarization and time-dependent $i$, suggesting that the protective ability of the passive film decreased with the increase in the heat input.

Table 5: $N_{\mathrm{A}}$ in the passive films formed on the surfaces of the SAF 2507 welded joints in $3.5 \% \mathrm{NaCl}$ solution

\begin{tabular}{|c|c|}
\hline Welding process & $N_{\mathrm{A}}\left(\mathrm{cm}^{-3}\right)$ \\
\hline LBW & $4.59 \times 10^{32}$ \\
\hline LGH & $6.64 \times 10^{32}$ \\
\hline GTAW & $8.35 \times 10^{32}$ \\
\hline
\end{tabular}

\section{CONCLUSIONS}

In this paper, the effect of the welding heat input on the microstructure, nanoindentation behavior and corrosion performance of SAF 2507 SDSS was investigated. The results can be summarized as follows:

(1) The volume, size, shape and distribution of austenite were closely correlated to the heat input of the welding process.

(2) Although different heat inputs of the welding did not significantly change the elastic properties of ferrite and austenite, the hardness of the welded joints decreased with the increase in the heat input.

(3) The increase in the passive-current density and donor concentration in the passive film indicated that the structure and property of the passive film formed on the surfaces of the welded joints changed and thus the corrosion susceptibility increased as the welding heat input increased.

\section{Acknowledgement}

The authors would like to acknowledge the financial support provided by the National Key Research and Development Program of China (No. 2018YFC0310400) and National Natural Science Foundation of China (No. 51911530211).

\section{REFERENCES}

${ }^{1}$ M. Breda, M. Pellizzari, M. Frigo, $\sigma$-phase in lean duplex stainless steel sheets, Acta Metall. Sin. Engl. Lett., 28 (2015), 331-337, doi:10.1007/s40195-014-0201-9

${ }^{2}$ G. Lothongkum, P. Wongpanya, S. Morito, T. Furuhara, T. Maki, Effect of nitrogen on corrosion behavior of $28 \mathrm{Cr}-7 \mathrm{Ni}$ duplex and microduplex stainless steels in air-saturated $3.5 w / \% \mathrm{NaCl}$ solution, Corros. Sci., 48 (2006), 137-153, doi:10.1016/j.corsci.2004.11.017

${ }^{3}$ S. T. Kim, S. H. Jang, I. S. Lee, Y. S. Park, Effects of solution heat-treatment and nitrogen in shielding gas on the resistance to pitting corrosion of hyper duplex stainless steel welds, Corros. Sci., 53 (2011), 1939-1947, doi:10.1016/j.corsci.2011.02.013

${ }^{4}$ A. Moteshakker, I. Danaee, Microstructure and corrosion resistance of dissimilar weld-joints between duplex stainless steel 2205 and austenitic stainless steel 316L, J. Mater. Sci. Technol., 32 (2016), 282-290, doi:10.1016/j.jmst.2015.11.021

${ }^{5}$ K. Qi, R. F. Li, G. J. Wang, G. Z. Li, B. Liu, M. F. Wu, Microstructure and corrosion properties of laser-welded SAF 2507 super duplex stainless steel joints, J. Mater. Eng. Perform., 28 (2019), 287-295, doi:10.1007/s11665-018-3833-5

${ }^{6}$ H. S. Bang, H. S. Bang, Y. C. Kim, I. H. Oh, A study on mechanical and microstructure characteristics of the STS304L butt joints using hybrid $\mathrm{CO}_{2}$ laser-gas metal arc welding, Mater. Des., 32 (2011), 2328-2333, doi:10.1016/j.matdes.2010.12.039

${ }^{7}$ Z. P. Shi, Z. B. Wang, J. Q. Wang, Y. X. Qiao, H. N. Chen, T. Y. Xiong, Y. G. Zheng, Effect of Ni interlayer on cavitation erosion resistance of NiTi cladding by tungsten inert gas (TIG) surfacing process, Acta Metall. Sin. Engl. Lett., 33 (2020), 415-424, doi:10.1007/s40195-019-00947-7

${ }^{8}$ X. X. Li, H. Zhang, Analysis of microstructure and properties of welded joint of high nitrogen steel by hybrid welding, Mater. Res. Express, 6 (2019), 045602, doi:10.1088/2053-1591/aaf9e5

${ }^{9}$ G. Tang, X. Zhao, R. D. Li, Y. Liang, Y. S. Jiang, H. Chen, Microstructure and properties of laser-arc hybrid welding thick bainitic steel joints with different arc position, Mater. Res. Express, 6 (2019), 076547, doi:10.1088/2053-1591/ab1557

${ }^{10}$ K. D. Ramkumar, D. Mishra, M. K. Vignesh, B. G. Raj, N. Arivazhagan, S. V. Naren, S. S. Kumar, Metallurgical and mechanical characterization of electron beam welded super-duplex stainless steel UNS 32750, J. Manuf. Process., 16 (2014), 527-534, doi:10.1016/j.jmapro.2014.07.011

${ }^{11}$ L. L. Liu, Y. F. Jia, F. Z. Xuan, Gradient effect in the waved interfacial layer of 304L/533B bimetallic plates induced by explosive welding, Mate. Sci. Eng. A, 704 (2017), 493-502, doi:10.1016/j.msea. 2017.08.012

${ }^{12}$ Y. S. Kim, J. G. Kim, Investigation of weld corrosion effects on the stress behavior of a welded joint pipe using numerical simulations, Met. Mater. Int., 25 (2019), 918-929, doi:10.1007/s12540019-00260-z

${ }^{13}$ P. Sathiya, M. K. Mishra, B. Shanmugarajan, Effect of shielding gases on microstructure and mechanical properties of super austenitic stainless steel by hybrid welding, Mater. Des., 33 (2012), 203-212, doi:10.1016/j.matdes.2011.06.065

${ }^{14}$ S. Sabooni, F. Karimzadeh, M. H. Enayati, A. H. W. Ngan, H. Jabbari, Gas tungsten arc welding and friction stir welding of ultrafine grained AISI 304L stainless steel: Microstructural and mechanical behavior characterization, Mater. Charact., 109 (2015), 138-151 doi:10.1016/j.matchar.2015.08.009 
${ }^{15}$ E. Taban, E. Kaluc, Welding behaviour of duplex and superduplex stainless steels using laser and plasma ARC welding processes, Weld. World, 55 (2011), 48-57, doi:10.1007/BF03321307

${ }^{16}$ K. Kumar, M. Masanta, S. K. Sahoo, Microstructure evolution and metallurgical characteristic of bead-on-plate TIG welding of Ti-6Al-4V alloy, J. Mater. Process. Technol., 265 (2019), 34-43, doi:10.1016/j.jmatprotec.2018.10.002

${ }^{17}$ Y. X. Qiao, J. Chen, H. L. Zhou, Y. X. Wang, Q. N. Song, H. B. Li, Z. B. Zheng, Effect of solution treatment on cavitation erosion behavior of high-nitrogen austenitic stainless steel, Wear, 424-425 (2019), 70-77, doi:10.1016/j.wear.2019.01.098

${ }^{18}$ Y. X. Qiao, X. Cai, J. Cui, H. B. Li, Passivity and semiconducting behavior of a high nitrogen stainless steel in acidic $\mathrm{NaCl}$ solution, Adv. Mater. Sci. Eng., (2016), 6065481, doi:10.1155/2016/6065481

${ }^{19}$ Y. X. Qiao, Z. H. Tian, X. Cai, J. Chen, Y. X. Wang, Q. N. Song, H. B. Li, Cavitation erosion behaviors of a nickel-free high-nitrogen stainless steel, Tribol. Lett., 67 (2019), 1-9, doi:10.1007/s11249018-1118-7

${ }^{20}$ V. Muthupandi, P. Bala Srinivasan, S. K. Seshadri, S. Sundaresan, Effect of weld metal chemistry and heat input on the structure and properties of duplex stainless steel welds, Mate. Sci. Eng. A, 358 (2003), 9-16, doi:10.1016/S0921-5093(03)00077-7

${ }^{21}$ P. Datta, G. S. Upadhyaya, Sintered duplex stainless steels from premixes of 316L and 434L powders, Mater. Chem. Phy., 67 (2001) 234-242, pii: S0254-0584(00)00477-6

${ }^{22}$ A. Garcia-Junceda, C. Diaz-Rivera, V. Gomez-Torralba, M. Rincon, M. Campos, J. Manuel Torralba, Analysis of the interface and mechanical properties of field-assisted sintered duplex stainless steels, Mate. Sci. Eng. A, 740 (2019), 410-419, doi:10.1016/j.msea.2018. 10.111

${ }^{23}$ L. M. Zhang, S. D. Zhang, A. L. Ma, H. X. Hu, Y. G. Zheng, B. J. Yang, J. Q. Wang, Influence of sealing treatment on the corrosion behavior of HVAF sprayed Al-based amorphous/nanocrystalline coating, Surf. Coat. Tech., 353 (2018), 263-273, doi:10.1016/j.surfcoat. 2018.08.086

${ }^{24}$ H. Somekawa, T. Mukai, Hall-Petch relation for deformation twinning in solid solution magnesium alloys, Mate. Sci. Eng. A, 561 (2013), 378-385, doi:10.1016/j.msea.2012.10.040

${ }^{25}$ Z. Y. Cui, L. W. Wang, M. Y. Zhong, F. Ge, H. Gao, C. Man, C. Liu, $\mathrm{X}$. Wang, Electrochemical behavior and surface characteristics of pure titanium during corrosion in simulated desulfurized flue gas condensates, J. Electrochem. Soc., 165 (2018), C542-C561, doi:10.1149/2.1321809jes

${ }^{26}$ Y. X. Qiao, Y. Zhou, S. J. Chen, Q. N. Song, Effect of bobbin tool friction stir welding on microstructure and corrosion behavior of 6061-T6 aluminum alloy joint in $3.5 \% \mathrm{NaCl}$ solution, Acta Metall Sin., 52 (2016), 1395-1402, doi:10.11900/0412.1961.2016.00026

${ }^{27}$ Y. Fu, X. Q. Wu, E. H. Han, W. Ke, K. Yang, Z. H. Jiang, Effects of nitrogen on the passivation of nickel-free high nitrogen and manganese stainless steels in acidic chloride solutions, Electrochim. Acta, 54 (2009), 4005-4014, doi:10.1016/j.electacta.2009.02.024
${ }^{28}$ Y. Fu, X. Q. Wu, E. H. Han, W. Ke, K. Yang, Z. H. Jiang, Influence of cold work on pitting corrosion behavior of a high nitrogen stainless steel, J. Electrochem. Soc., 155 (2008), C455-C463, doi:10.1149/1.2939213

${ }^{29}$ S. Ningshen, U. Kamachi Mudali, V. K. Mittal, H. S. Khatak, Semiconducting and passive film properties of nitrogen-containing type 316LN stainless steels, Corros. Sci., 49 (2007), 481-496, doi:10.1016/j.corsci.2006.05.041

${ }^{30}$ Y. X. Qiao, D. K. Xu, S. Wang, Y. J. Ma, J. Chen, Y. X. Wang, H. L. Zhou, Corrosion and tensile behaviors of Ti-4Al-2V-1Mo-1Fe and Ti-6Al-4V titanium alloys, Metals, 9 (2019), 1213, doi:10.3390/met9111213

${ }^{31}$ Y. X. Qiao, Y. G. Zheng, P. C. Okafor, W. Ke, Electrochemical behaviour of high nitrogen bearing stainless steel in acidic chloride solution: Effects of oxygen, acid concentration and surface roughness, Electrochim. Acta, 54 (2009), 2298-2304, doi:10.1016/j.electacta. 2008.10.038

${ }^{32}$ H. B. Li, E. Z. Zhou, Y. B. Ren, D. W. Zhang, D. Xu, C. G. Yang, H. Feng, Z. Jiang, X. G. Li, T. Y. Gu, K. Yang, Investigation of microbiologically influenced corrosion of high nitrogen nickel-free stainless steel by Pseudomonas aeruginosa, Corros. Sci., 111 (2016), 811-821, doi:10.1016/j.corsci.2016.06.017

${ }^{33}$ E. Sikora, D. D. Macdonald, Nature of the passive film on nickel, Electrochim. Acta, 48 (2002), 69-77, doi:10.1016/S0013-4686(02) 00552-2

${ }^{34}$ Z. B. Wang, H. X. Hu, Y. G. Zheng, W. Ke, Y. X. Qiao, Comparison of the corrosion behavior of pure titanium and its alloys in fluoride-containing sulfuric acid, Corros. Sci., 103 (2016), 50-65, doi:10.1016/j.corsci.2015.11.003

${ }^{35}$ L. M. Zhang, M. C. Yan, S. D. Zhang, L. Y. Zhu, A. J. Umoh, A. L. Ma, Y. G. Zheng, J. Q. Wang, Significantly enhanced resistance to SRB corrosion via Fe-based amorphous coating designed with high dose corrosion-resistant and antibacterial elements, Corros. Sci., 164 (2020), 108305, doi:10.1016/j.corsci.2019.108305

${ }^{36}$ D. Song, J. Hao, F. L. Yang, H. D. Chen, N. N. Liang, Y. Y. Wu, J. C. Zhang, H. Ma, E. E. Klu, B. Gao, Y. X. Qiao, J. P. Sun, J. Y. Jiang, Corrosion behavior and mechanism of Cr-Mo alloyed steel: Role of ferrite/bainite duplex microstructure, J. Alloy Compd., 809 (2019), 151787, doi:10.1016/j.jallcom.2019.151787

${ }^{37}$ Y. X. Qiao, Y. G. Zheng, W. Ke, P. C. Okafor, Electrochemical behaviour of high nitrogen stainless steel in acidic solutions, Corros. Sci., 51 (2009), 979-986, doi:10.1016/j.corsci.2009.02.026

${ }^{38}$ M. Metikoš-Huković, R. Babić, Z. Grubač, Ž. Petrović, N. Lajçi, High corrosion resistance of austenitic stainless steel alloyed with nitrogen in an acid solution, Corros. Sci., 53 (2011), 2176-2183, doi:10.1016/j.corsci.2011.02.039

${ }^{39}$ H. Y. Ha, H. J. Jang, H. S. Kwon, S. J. Kim, Effects of nitrogen on the passivity of $\mathrm{Fe}-20 \mathrm{Cr}$ alloy, Corros. Sci., 51 (2009), 48-53, doi:10.1016/j.corsci.2008.10.017 